\title{
Differential Translational Efficiency of the mRNAs Isolated from Derepressed and Glucose Repressed Saccharomyces cerevisiae
}

\author{
By A. PARETS SOLER, * M. CASANOVA, D. GOZALBO AND \\ R. SENTANDREU \\ Departament de Microbiologia, Facultat de Farmacia, Universitat de València, \\ Avgda. Blasco Ibáñez 13, 46010 València, Spain
}

(Received 18 November 1986)

Carbon catabolite derepression induced changes in the pool of yeast mRNAs translatable in a protein-synthesizing reticulocyte system. Competition experiments with globin mRNA showed that the mRNA population obtained from derepressed cells possessed a higher translational efficiency than mRNA from repressed cells. The mRNAs that could account for the high translational efficiency of the derepressed mRNA were not detected in cells growing in glucoserich medium. Analysis of protein synthesis in the presence of 7-methylguanosine 5'-phosphate indicated that the initiation factors recognizing the 5 -terminal structure of capped messengers interacted with lower affinity with the repressed than with some specific derepressed mRNAs.

\section{INTRODUCTION}

The growth of Saccharomyces cerevisiae in the presence of glucose as fermentable carbon source results in the repression of a large number of enzyme activities. Thus, the synthesis of functional components of several pathways that are not required for glycolysis are repressed. Mitochondrial activities, such as components of the tricarboxylic acid cycle, the electron transport chain and oxidative phosphorylation, are decreased when glucose is available (K im \& Beattie, 1973; Perlman \& Mahler, 1974; Polakis \& Bartley, 1965). Cytoplasmic functions involved in gluconeogenesis and enzymes required for the catabolism of alternative sugars are also repressed (Adams, 1972; Gascon et al., 1968; Haarasilta \& Oura, 1975; Polakis \& Bartley, 1965). On the other hand, the levels of mitochondrial protein synthesis (Ibrahim et al., 1973) and transcription (Baldacci \& Zennaro, 1982; Kelly \& Phillips, 1983), as well as those of the nuclearencoded mitochondrial RNA polymerase (Lustig et al., 1982), are higher in derepressed than in glucose-repressed cells.

Glucose deprivation during cell growth is associated with derepression of the synthesis of a variety of enzyme activities, e.g. enzymes involved in utilizing ethanol as an energy and carbon source via oxidative respiration and gluconeogenesis, and those involved in maltose, galactose and sucrose utilization. The regulation of the synthesis of the above-mentioned cytoplasmic activities (Carlson \& Botstein, 1982; Denis et al., 1983; Federoff et al., 1983; Perlman \& Halvorson, 1981; St John \& Davis, 1981) and nuclear-encoded mitochondrial components (Hoosein \& Lewin, 1984; Lustig et al., 1982; Szekely \& Montgomery, 1984), has been shown to be exerted at the level of transcription.

Therefore, the yeast cells are able to respond rapidly to environmental changes by directing the synthesis of new sets of proteins according to cellular needs. We asked whether during carbon catabolite derepression, there was a change in the translational characteristics of the mRNAs. Indeed, when yeast cells were shifted from glucose-containing medium to derepressing conditions, the poly(A)-containing RNA population was able to initiate translation more efficiently.

Abbreviation: m? GMP, 7-methylguanosine 5'-phosphate. 


\section{METHODS}

Strain and culture conditions. S. cerevisiae strain X-2180-1A was obtained from the Yeast Genetic Stock Center, Berkeley, Calif., USA. Cells were grown aerobically to early-exponential phase at $28^{\circ} \mathrm{C}$ in YP medium $-1 \%(w / v)$ Yeast extract, $1 \%(w / v)$ Bacto-Peptone (Difco) - with $2 \%(w / v)$ glucose as the carbon source. Glucose-repressed yeast cells were harvested at $4{ }^{\circ} \mathrm{C}$, washed once in water, and RNA was isolated as described below. For conditions of carbon catabolite derepression, early-exponential-phase cells grown in the presence of $2 \%$ glucose were washed once in water, transferred to YP medium containing $0.05 \%$ glucose and incubated for 90 min. Derepressed cells were harvested at $4{ }^{\circ} \mathrm{C}$, washed once in water, and total RNA was isolated. Derepression was monitored by the appearance of external invertase activity (Elorza et al., 1977; Gascon et al., 1968).

Isolation of poly $(A)$-containing RNA from $S$. cerevisiae. Total RNA was isolated from either repressed or derepressed yeast cells by a modification of the procedure of Chirgwin et al. (1979). Early-exponential-phase cells $\left(4 \mathrm{~g}\right.$ wet $\mathrm{wt}$ ), harvested at $4{ }^{\circ} \mathrm{C}$ were washed once in water, resuspended in $70 \mathrm{ml} 4 \mathrm{M}$-guanidinium thiocyanate (Merck), $0.1 \mathrm{M}$-2-mercaptoethanol, $0.5 \%$ sodium $N$-lauroylsarcosine, $25 \mathrm{~mm}$-sodium citrate (pH 7.0), and disrupted by shaking for $12-15 \mathrm{~min}$ in a Vibrogen Cell Mill at $10^{\circ} \mathrm{C}$ in the presence of $160 \mathrm{~g}$ glass beads. The homogenate was centrifuged at $24000 \mathrm{~g}$ for $30 \mathrm{~min}$; the supernatant was mixed with 1 vol. ethanol (1 M-acetic acid was added to lower the $\mathrm{pH}$ from 7 to 5 ) and placed at $-20^{\circ} \mathrm{C}$ for $20 \mathrm{~h}$. The precipitate containing the RNA was collected by centrifugation at $16000 \mathrm{~g}$ for $10 \mathrm{~min}$ and was dissolved in $35 \mathrm{ml} 7.5 \mathrm{M}$-guanidine hydrochloride (Sigma), $5 \mathrm{~mm}$-dithiothreitol, $0.5 \%$ sodium $N$-lauroylsarcosine, $25 \mathrm{~mm}$-sodium citrate (pH 7.0). RNA was reprecipitated by adding $35 \mathrm{ml}$ ethanol and $1.75 \mathrm{ml} 1 \mathrm{M}$-acetic acid. The solution was kept for at least $8 \mathrm{~h}$ at $-20^{\circ} \mathrm{C}$ and the precipitate, collected by centrifugation at $16000 \mathrm{~g}$ for $30 \mathrm{~min}$, was redissolved in the guanidine hydrochloride reagent and reprecipitated as before.

The final RNA precipitate was dispersed twice in ethanol at room temperature (to extract excess guanidine hydrochloride) and centrifuged at $10000 \mathrm{~g}$ for $10 \mathrm{~min}$. Ethanol was removed from the pellet by a stream of nitrogen and the RNA was dissolved in $20 \mathrm{ml} 20 \mathrm{~mm}-\mathrm{Tris} / \mathrm{HCl}(\mathrm{pH} 7.5), 500 \mathrm{mM}-\mathrm{NaCl}, 10 \mathrm{mM}-\mathrm{EDTA}, 0.2 \%$ sodium $N$ lauroylsarcosine. Polyadenylated RNA was isolated from total RNA by poly(U)-Sepharose chromatography (Pharmacia). The recovery of poly(A)-containing RNA from repressed and derepressed yeast was approximately 0.5 and $0.25 \mathrm{mg}$ ( $\mathrm{g}$ wet cells) $)^{-1}$ respectively. In either case, mRNA preparations had an $A_{260} / A_{280}$ ratio of between $1 \cdot 9$ and $2 \cdot 1$.

Preparation of initiation factors from reticulocyte polysomes. Polyribosomes isolated from reticulocytes of phenylhydrazine-treated rabbits were extracted with $0.5 \mathrm{M}-\mathrm{KCl}$ (Staehelin et al., 1979). The ribosomal salt wash, dialysed against buffer A (20 mM-Tris/HCl, pH 7.5; 1-mM DTT; $0.05 \mathrm{mM-EDTA;} 10 \%$, v/v, glycerol) containing $0 \cdot 1 \mathrm{M}-\mathrm{KCl}$, was applied to a DEAE-Sephadex A-25 column equilibrated in buffer $\mathrm{A}-0 \cdot 1 \mathrm{M}-\mathrm{KCl}$. The material which did not bind to the column contained inhibitory activities (Parets Soler et al., 1981) and was discarded. The material retained was eluted with buffer A-0.35 $\mathrm{M}-\mathrm{KCl}$ and concentrated by the addition of crystalline $\left(\mathrm{NH}_{4}\right)_{2} \mathrm{SO}_{4}$ to $80 \%$ saturation. The precipitate was collected by centrifugation, dissolved in buffer $\mathrm{A}-0 \cdot 1 \mathrm{M}-\mathrm{KCl}$ and dialysed against the same buffer. This material constituted the preparation of crude initiation factors utilized in experiments reported here.

Preparation of globin $m R N A$. The poly(A)-containing RNA species from rabbit reticulocyte polysomes were prepared by affinity chromatography according to Krystosek et al. (1975).

Protein synthesis in reticulocyte lysates. Rabbit reticulocytes were lysed with 1 vol. ice-cold water and then supplemented with $25 \mu \mathrm{M}$-haemin, $50 \mu \mathrm{g}$ creatine phosphokinase $\mathrm{ml}^{-1}$ and $2 \mathrm{mM}$-DTT. The preparation was treated with micrococcal nuclease as described by Pelham \& Jackson (1976). The cell-free system contained in a final volume of $30 \mu \mathrm{l}: 10 \mu \mathrm{l}$ nuclease-treated lysate; $1 \mathrm{mM}-\mathrm{ATP} ; 0.2 \mathrm{mM}-\mathrm{GTP} ; 10 \mathrm{~mm}$-creatine phosphate; $60 \mu \mathrm{g}$ creatine phosphokinase $\mathrm{ml}^{-1} ; 40 \mu \mathrm{M}$ of each of the amino acids except leucine; $0.33 \mathrm{mCi} \mathrm{ml}^{-1}\left[{ }^{3} \mathrm{H}\right] \mathrm{leucine}$

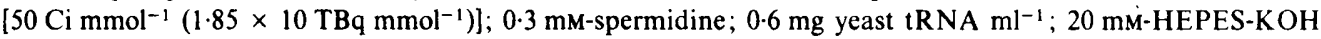
(pH 7.5); $0.25 \mathrm{~mm}$-magnesium acetate; $100 \mathrm{~mm}-\mathrm{KCl}$; and the indicated concentrations of mRNAs. Unless otherwise indicated, protein synthesis was stopped by dilution with $30 \mu \mathrm{l}$ ice-cold water after $70 \mathrm{~min}$ incubation at $35^{\circ} \mathrm{C}$.

To measure the rate of the initiation of polypeptide chains, the initiation of translation was blocked at the indicated time of incubation by addition of $1 \mu \mathrm{l}$ aurintricarboxylic acid to $150 \mu \mathrm{M}$ final concentration (under these conditions elongation was unaffected). The incubation was continued for another 30 min to complete the nascent polypeptide chains.

To determine incorporation of $\left[{ }^{3} \mathrm{H}\right]$ leucine into polypeptide chains, equal volumes of reaction mixture were made up to $0.3 \mathrm{M}-\mathrm{NaOH}, 1 \cdot 7 \%(\mathrm{v} / \mathrm{v}) \mathrm{H}_{2} \mathrm{O}_{2}$ and $2 \mathrm{~mm}$-leucine. After $15 \mathrm{~min}$ at $35^{\circ} \mathrm{C}$ the mixture was precipitated with $1 \mathrm{ml} 25 \%$ trichloroacetic acid at $4{ }^{\circ} \mathrm{C}$.

Analytical SDS gel electrophoresis was performed on $12 \%(w / v)$ polyacrylamide gels (Laemmli, 1970). Samples $(1 \mu \mathrm{l})$ of the reaction mixture were resolved on urea/12\% polyacrylamide gels, containing Triton X-100, in order to quantify the synthesis of the globin chains according to Rovera et al. (1978). The gels were dried and fluorographed at $-70^{\circ} \mathrm{C}$. Alternatively, to quantify globin synthesis, the gels were stained with Coomassie brilliant blue, destained and dried. The $\alpha$ - and $\beta$-globin bands were cut out, hydrated with $200 \mu$ water, and digested with $2 \mathrm{ml}$ 


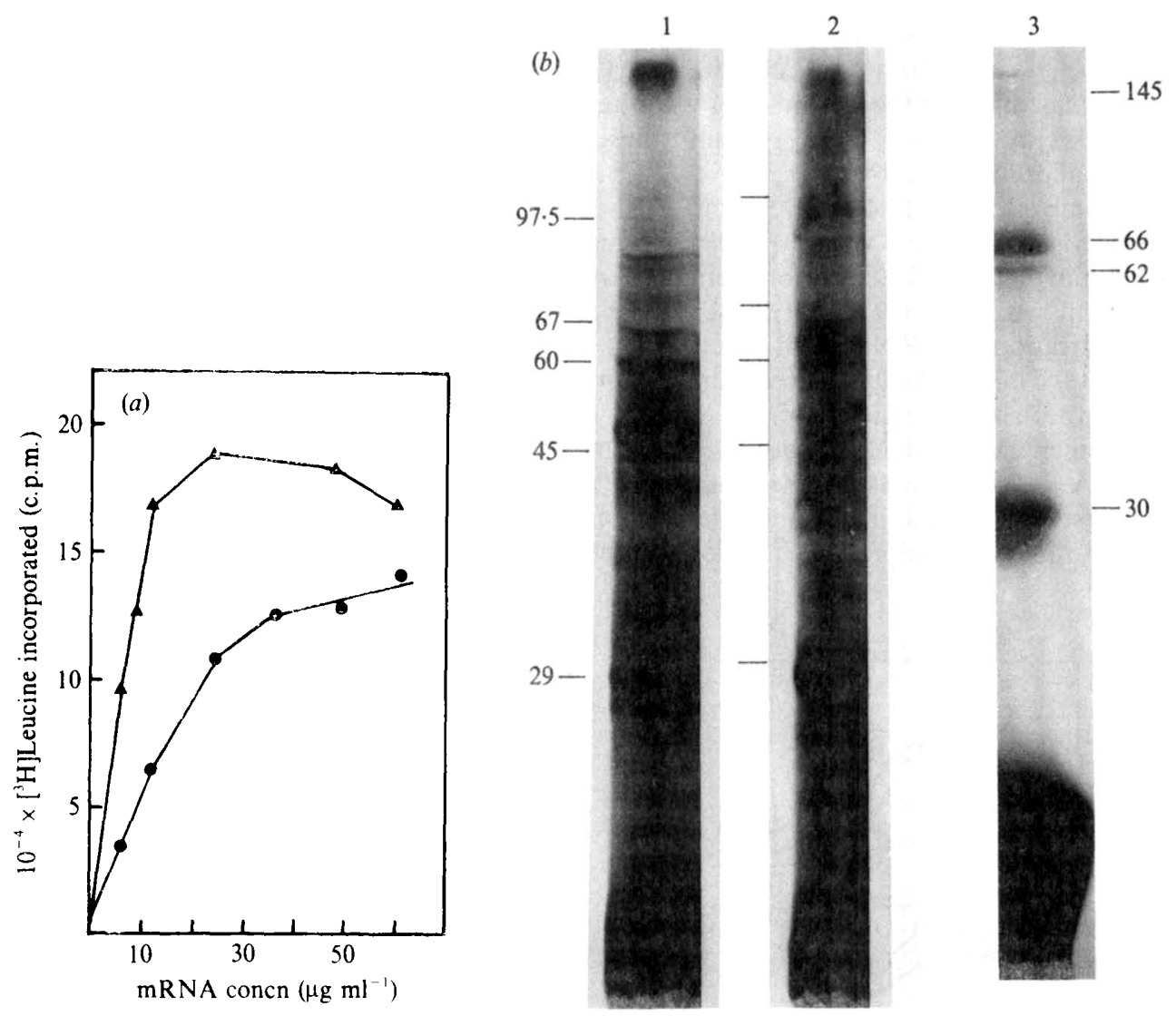

Fig. 1. Protein synthesis directed by yeast mRNA in reticulocyte lysates. (a) Translation of increasing amounts of poly (A)-containing RNA from yeast growing under glucose-repressed $(O)$ or derepressed (A) conditions. (b) SDS-polyacrylamide gel of the products encoded by the mRNA from repressed yeast (lane 1), derepressed yeast (lane 2), and reticulocyte polysomes (lane 3 ). Reticulocyte mRNA encoded major polypeptides of $30,62,66$ and $145 \mathrm{kDa}$ in addition to the globin. Marker proteins (molecular mass, $\mathrm{kDa}$ ) are: carbonic anhydrase (29), ovalbumin (45), catalase (60), bovine serum albumin (67) and phosphorylase $b(97 \cdot 5)$.

NCS tissue solubilizer ( $A$ mersham) at $50^{\circ} \mathrm{C}$ for $2 \mathrm{~h}$; the radioactivity was determined by liquid scintillation counting.

\section{RESULTS}

\section{Yeast $m R N A$ concentration curves}

The translational capacity of the poly(A)-containing RNA isolated from $S$. cerevisiae growing under derepressed or glucose-repressed conditions was assayed in an mRNA-dependent reticulocyte lysate. Higher levels of protein synthesis were obtained with the mRNA from derepressed cells than with the mRNA from repressed cells (Fig. $1 a$ ). The mRNA concentration curves showed a linear increase of protein synthesis when the mRNA concentration from either derepressed or repressed cells was raised to about 12 or $24 \mu \mathrm{g} \mathrm{ml}^{-1}$ respectively. Fig. $1(b)$ shows that one-dimensional gel electrophoresis was sufficient to reveal some differences between the major polypeptide bands encoded by each of these two mRNA populations.

\section{Competitive abilities of $m R N A s$ from repressed and derepressed yeast}

The dependence of the protein synthesis rate upon mRNA concentration suggested that the translational efficiency of mRNAs from derepressed cells might be higher than that from repressed cells. In order to ascertain the relative affinity of these two yeast mRNA populations for the reticulocyte translational machinery, competition experiments between yeast and 
reticulocyte mRNAs were carried out. For this purpose, advantage was taken of the fact that at high $\mathrm{KCl}$ concentrations $(100 \mathrm{mM})$, poly(A)-containing RNA isolated from reticulocyte polysomes directed the synthesis of a limited number of major polypeptides $(30,62,66$ and $145 \mathrm{kDa}$ ) in addition to the globin; these were easy to identify and quantify after gel electrophoresis (Fig. 1b, lane 3).

Initially the effect of the yeast mRNA populations on the synthesis of the polypeptides encoded by the reticulocyte mRNAs was analysed. Yeast protein synthesis increased linearly when the mRNA concentration from derepressed or repressed cells was increased up to 12 or $24 \mu \mathrm{g} \mathrm{ml}^{-1}$ respectively (Fig. $1 a$ ): hence, for experiments of messenger competition, a suitable concentration of mRNA from derepressed cells appeared to be $21 \mu \mathrm{g} \mathrm{ml}^{-1}$ (Fig. 1a), i.e. an increase of 1.75-fold with respect to an mRNA concentration of $12 \mu \mathrm{g} \mathrm{ml}^{-1}$. Therefore, in order to preserve a similar increase of the mRNA level, a concentration of $43 \mu \mathrm{g} \mathrm{ml}^{-1}$ was used for experiments with mRNA from repressed cells. In addition, as shown below (Fig. 3), these yeast mRNA concentrations reduced similarly (to approximately $80 \%$ of the control value) the synthesis of the globin directed by a nearly saturating concentration of reticulocyte mRNA $\left(27 \mu \mathrm{g} \mathrm{ml}^{-1}\right)$; a titration curve for globin mRNA is shown in Fig. 2(c). On the other hand, since

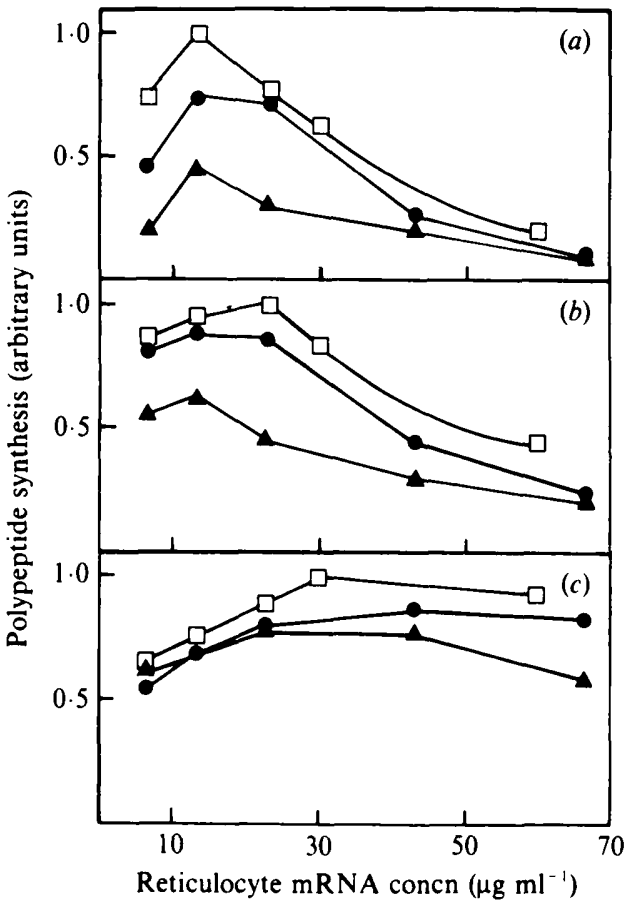

Fig. 2.

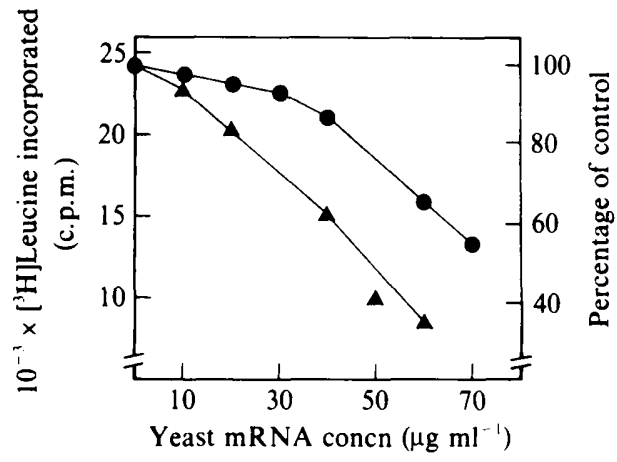

Fig. 3

Fig. 2. Translational competition between yeast and reticulocyte mRNAs in reticulocyte lysates. Increasing amounts of poly(A)-containing RNA from reticulocyte polysomes were translated with a constant amount of mRNA from repressed $\left(43 \mu \mathrm{g} \mathrm{ml}^{-1}, 0\right)$ or derepressed $\left(21 \mu \mathrm{g} \mathrm{ml}^{-1}, \Delta\right)$ yeast cells; a control experiment without yeast mRNA was also done $(\square)$. Synthesis of the $145 \mathrm{kDa}(a), 66 \mathrm{kDa}(b)$ and globin ( $\alpha$-plus $\beta$-chains; $c$ ) polypeptides was quantified by densitometric analysis of the fluorograms after electrophoresis on SDS- or urea-gels. The maximum intensity obtained for each polypeptide band has arbitrarily been taken as one unit.

Fig. 3. Effect of yeast mRNA on globin mRNA translation. A constant amount of poly(A)-containing RNA from reticulocyte polysomes $\left(27 \mu \mathrm{g} \mathrm{ml}^{-1}\right)$ was translated in the presence of increasing amounts of yeast mRNA from either repressed ( $)$ or derepressed $(\boldsymbol{\Lambda})$ cells. Samples of the reaction mixtures were electrophoresed on urea gels in order to quantify the radioactivity incorporated in globin ( $\alpha$ - plus $\beta$ chains) by liquid scintillation counting. 
the efficiency of translation of the mRNAs encoding the 66 and $145 \mathrm{kDa}$ polypeptides was known to be lower than that of the globin mRNA, the above yeast mRNA concentrations appeared to be suitable to detect differences in the synthesis of the reticulocyte polypeptides due to the presence of mRNA from either repressed or derepressed yeast cells.

Increasing amounts of a poly(A)-containing RNA preparation from reticulocytes (6.7$67 \mu \mathrm{g} \mathrm{ml}^{-1}$ ) were added to the reaction mixtures containing mRNA from either repressed $\left(43 \mu \mathrm{g} \mathrm{ml}^{-1}\right)$ or derepressed $\left(21 \mu \mathrm{g} \mathrm{ml}^{-1}\right)$ cells. Samples of the translation products were electrophoresed on either SDS- or urea-gels in order to quantify the synthesis of the reticulocyte polypeptides by densitometric analysis of the fluorograms. Figs $2(a)$ and $2(b)$ show that the synthesis of the 66 and $145 \mathrm{kDa}$ polypeptides was lower when competition experiments were carried out with mRNA from derepressed compared with mRNA from repressed cells. It should be noted that despite the fact that the total mRNA concentration was higher in reaction mixtures containing mRNA from repressed cells, i.e. conditions of higher messenger competition, the interaction of the mRNAs encoding the 66 and $145 \mathrm{kDa}$ polypeptides with the translational machinery was affected more in reaction mixtures containing mRNA from derepressed cells, where the total mRNA concentration was lower. Hence, these results suggested a higher affinity for the translational machinery of the mRNA population from derepressed versus repressed yeast cells. When the total mRNA concentration was increased in reaction mixtures containing mRNA from either repressed or derepressed cells, the synthesis of the 66 and $145 \mathrm{kDa}$ polypeptides was outcompeted by the globin mRNA. The 30 and $62 \mathrm{kDa}$ polypeptides were not taken into account since the mRNA from yeast cells directed the synthesis of major polypeptides around $30 \mathrm{kDa}$, and the mRNA from derepressed yeast encoded a $62 \mathrm{kDa}$ polypeptide band that was not detected with mRNA from repressed cells (see also Fig. 6).

The ability of the mRNA preparations from either repressed or derepressed cells to compete with globin mRNA were analysed better in the experiment reported in Fig. 3, in which a constant concentration of reticulocyte mRNA $\left(27 \mu \mathrm{g} \mathrm{ml}^{-1}\right)$ was titrated against increasing amounts of yeast mRNA. Samples of the translation products were electrophoresed on urea-gels and the radioactivity incorporated in globin chains was measured. The addition of mRNA from either repressed or derepressed yeast cells at concentrations higher than $10 \mu \mathrm{g} \mathrm{ml}^{-1}$ reduced the translation of globin mRNA, but the effect was more pronounced with mRNA from the derepressed cells. Concentrations up to $30 \mu \mathrm{g} \mathrm{ml}^{-1}$ of mRNA from repressed cells did not markedly affect the synthesis of globin, while a similar concentration of mRNA from derepressed cells reduced it to $70 \%$ of the control value (Fig. 3). Thus, a higher competitive ability of the mRNA preparation isolated from derepressed cells, as compared to repressed cells, was again observed.

The above data might be explained if some mRNAs with high translational efficiencies were present in derepressed cells but absent from cells growing on glucose. This conclusion was further supported by the data presented in Fig. 4, where the relative initiation of the synthesis of the major polypeptides was measured as a function of time, in the presence of globin mRNA to allow only the expression of the most efficient yeast mRNAs. When high concentrations of mRNA from yeast cells $\left(36 \mu \mathrm{g} \mathrm{ml}^{-1}\right)$ were translated in the presence of a saturating concentration of reticulocyte mRNA $\left(45 \mu \mathrm{g} \mathrm{ml}^{-1}\right)$, the level of protein synthesis directed by the mRNA from repressed cells (Fig. $4 a$ ) was lower than that from derepressed cells (Fig. $4 c$ ). Hence, it was necessary to decrease the reticulocyte mRNA concentration to $27 \mu \mathrm{g} \mathrm{ml}^{-1}$ in order to analyse the synthesis of the major polypeptides encoded by the most efficient mRNAs isolated from repressed cells. Under these conditions, there was initiation of the 28, 29 and $110 \mathrm{kDa}$ polypeptide bands during the first $5 \mathrm{~min}$ of incubation (Fig. $4 \mathrm{~b}$ ). In contrast, with mRNA from derepressed cells, polypeptide bands of about $28,29,43,48,52,62,64$ and $110 \mathrm{kDa}$ were initiated during the first 2 min of incubation despite the presence of $45 \mu \mathrm{g}$ reticulocyte mRNA ml-1 (Fig. 4c). After 8 min of initiation, additional polypeptide bands of about 32, 43, $46,52,59$ and $64 \mathrm{kDa}$ were observed with mRNA from repressed cells and polypeptide bands of about $20,22,25,32,34,36,38,46$ and $57 \mathrm{kDa}$ with mRNA from derepressed cells. These differences observed in the initiation rates between polypeptides encoded by repressed and 

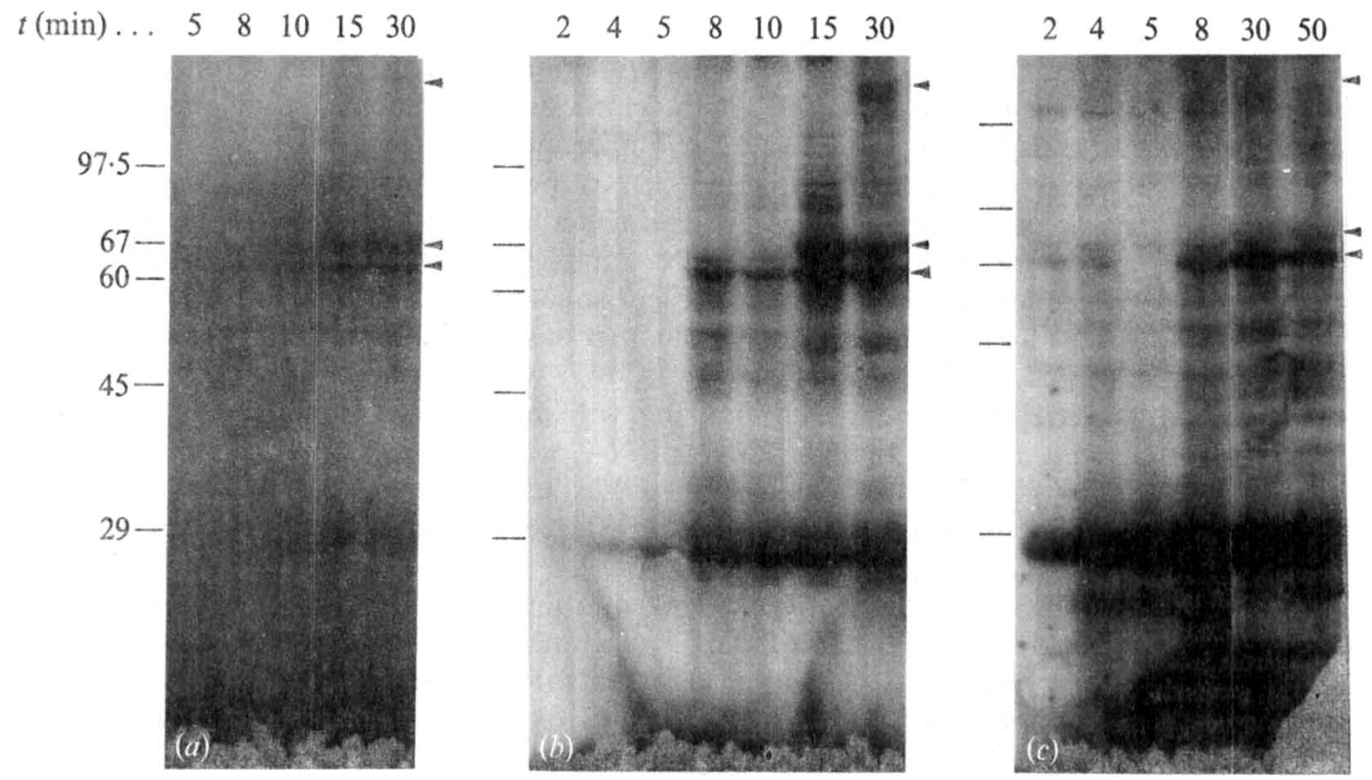

Fig. 4. Kinetics of the translational initiation of the most efficient yeast mRNAs. Poly(A)-containing RNA from reticulocyte polysomes was incubated in reaction mixtures in the presence of yeast mRNA from repressed $(a, b)$ or derepressed $(c)$ cells. The concentrations of reticulocyte mRNA and yeast mRNA respectively were: 45 and $36 \mu \mathrm{g} \mathrm{ml}^{-1}(a, c) ; 27$ and $40 \mu \mathrm{g} \mathrm{ml}^{-1}(b)$. At the indicated time, aurintricarboxylic acid $(150 \mu \mathrm{M})$ was added and the incubation was continued for another $30 \mathrm{~min}$ to complete the nascent polypeptide chains. The translation products were analysed by SDSpolyacrylamide gel electrophoresis and fluorography. The arrowheads show the position of the 62,66 and $145 \mathrm{kDa}$ polypeptide bands encoded by the poly(A)-containing RNA from reticulocyte polysomes.

derepressed cells revealed the presence in derepressed yeast of some mRNAs with a capacity to interact efficiently with the reticulocyte translational machinery; in particular, major polypeptide bands of $20,22,36,38,48$ and $57 \mathrm{kDa}$ that were not detected among the products encoded by the mRNA from repressed cells were observed. The kinetics of initiation of synthesis of the polypeptides of highest molecular mass, detected under these experimental conditions after 8 min of translational initiation, were similar with mRNA from repressed or derepressed cells (e.g. 85, 89, 95, 100, 120 and $125 \mathrm{kDa}$ : Fig. 4b,c).

The results from Fig. 3, showing that globin synthesis was outcompeted by mRNA from derepressed yeast cells and little affected by the presence of mRNA from repressed yeast cells, taken with those in Fig. 2, also indicated that the mRNA preparation from repressed yeast did not contain translational inhibitors that could be responsible for the differences in translational efficiencies observed here.

\section{Translational dependence of yeast $m R N A s$ upon cap structure}

To achieve a greater understanding of the above differences in mRNA translational capacity, the effect of different concentrations of the inhibitor 7-methylguanosine $5^{\prime}$-phosphate $\left(\mathrm{m}^{7} \mathrm{GMP}\right)$ was determined in the presence of a constant amount of mRNA from either repressed or derepressed cells. Translation of the mRNA from repressed cells was greatly inhibited with low concentrations of this analogue of the 5'-terminal cap structure of mRNAs $\left(0.25 \mathrm{mM}-\mathrm{m}^{7} \mathrm{GMP}\right.$ caused $50 \%$ inhibition) (Fig. $5 a$ ) ; the translation of the mRNA from derepressed cells was less affected $\left(0.9 \mathrm{mM}-\mathrm{m}^{7} \mathrm{GMP}\right.$ caused $50 \%$ inhibition). Therefore, the mRNA from repressed cells appeared to interact with lower affinity with the reticulocyte translational machinery than the yeast mRNA obtained under derepressing conditions. The translation products were analysed by SDS-polyacrylamide gel electrophoresis and fluorography: as expected, low $\mathrm{m}^{7} \mathrm{GMP}$ concentrations $(0.05$ to $0.2 \mathrm{~mm})$ affected the synthesis of the major polypeptides encoded by the 


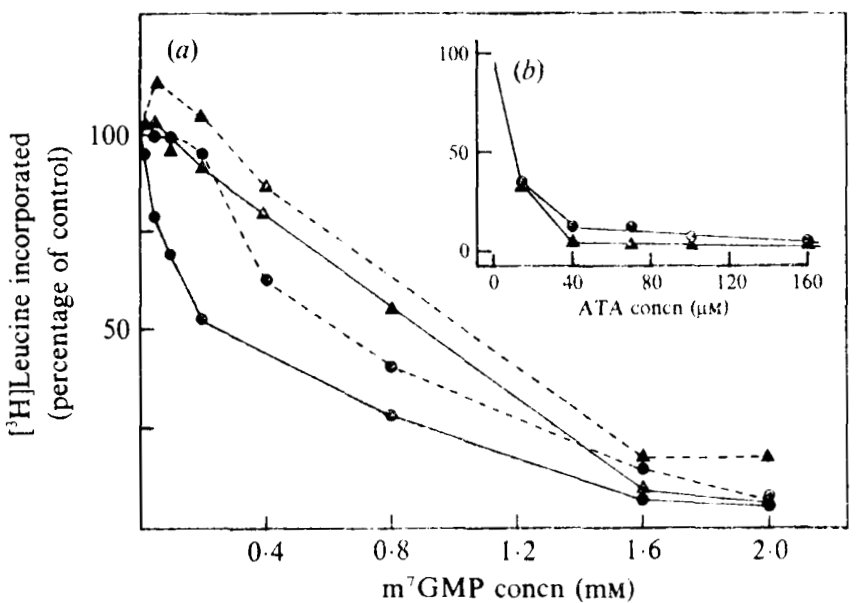

Fig. 5. Effect of inhibitors of initiation of protein synthesis on yeast mRNA translation. A constant amount of mRNA from repressed $\left(43 \mu \mathrm{g} \mathrm{ml}^{-1}, 0\right)$ or derepressed $\left(21 \mu \mathrm{g} \mathrm{ml}^{-1}, \Delta\right)$ yeast cells was translated in the presence of increasing concentrations of $\mathrm{m}^{7} \mathrm{GMP}(a)$ or aurintricarboxylic acid (ATA) (b). Reaction mixtures were incubated in the absence (-) or in the presence (---) of $32 \mu \mathrm{g}$ of initiation factors from rabbit reticulocytes. Controls of $\left[{ }^{3} \mathrm{H}\right]$ leucine incorporation without inhibitors $(\equiv 100 \%$; measured in $5 \mu$ of reaction mixture) were $16050(\mathbf{O})$ and 23935 c.p.rn. $(\Delta)$ in the absence of initiation factors, and $21774(\boldsymbol{)})$ and 32486 c.p.m. $(\boldsymbol{\Delta})$ in their presence.

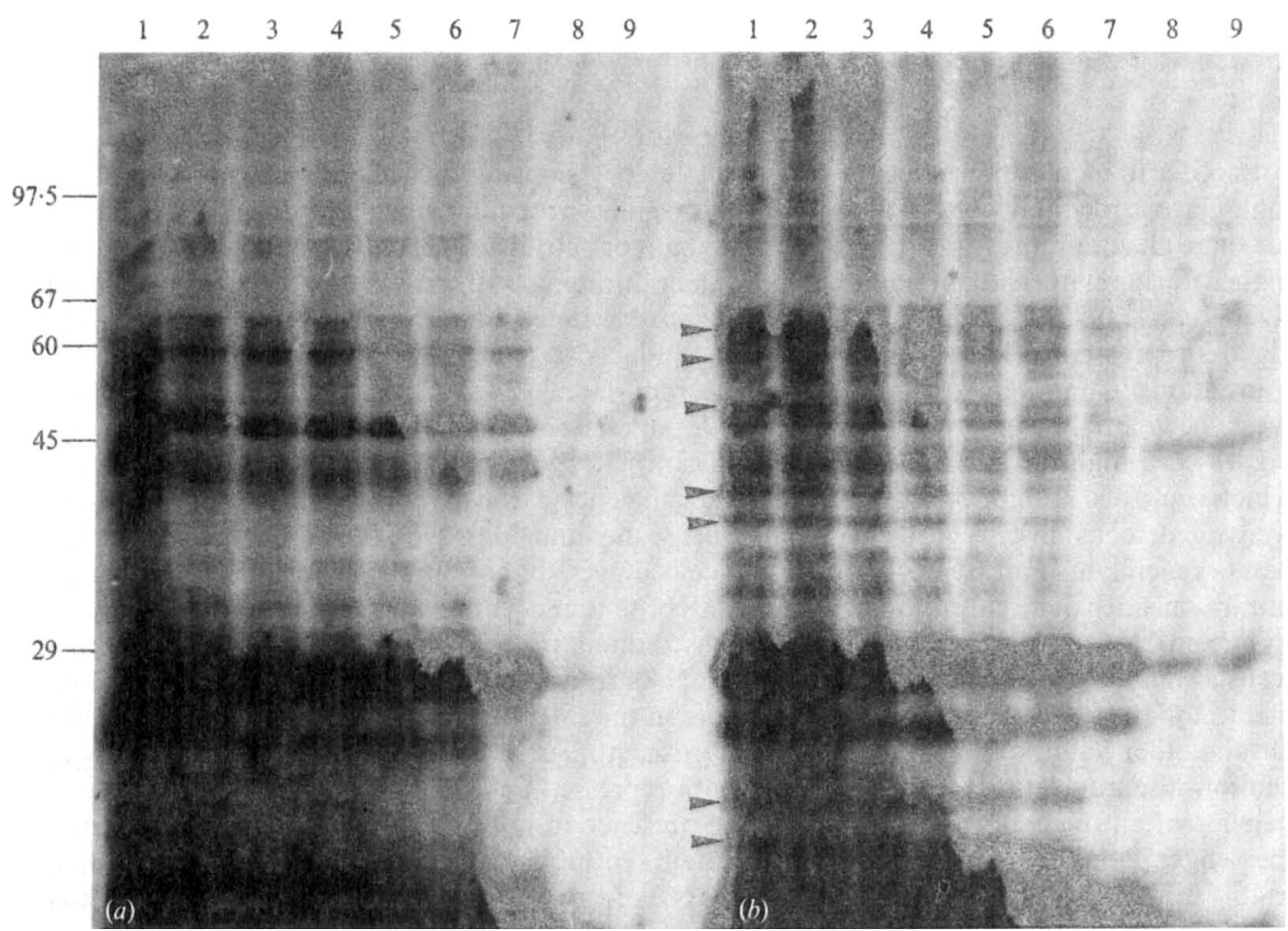

Fig. 6. Products directed by yeast $m$ RNAs in the presence of $m^{7} G M P$. The polypeptides synthesized in the presence of mRNA from repressed $(a)$ or derepressed $(b)$ yeast in the experiment reported in Fig. 5 without initiation factors were analysed by SDS-polyacrylamide gel electrophoresis and fluorography.

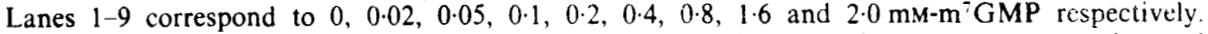
Arrowheads indicate polypeptides encoded by mRNAs from derepressed yeast that were not detected in glucose growing cells. 
mRNA from derepressed (Fig. $6 b$ ) less than those from repressed cells (Fig. $6 a$ ). It should be noted that some of the polypeptides encoded by the derepressed mRNA, whose synthesis was affected only by $\mathrm{m}^{7} \mathrm{GMP}$ concentrations higher than $0.1 \mathrm{mM}$, were absent from the products encoded by the repressed mRNA e.g., polypeptides of about $20,22,36,38,48,57$, and $62 \mathrm{kDa}$ (Fig. 6b).

The translational efficiency of mRNAs is dependent both on their affinity for some initiation factors and on the availability of the latter (Lodish, 1974; Parets Soler et al., 1984; Ray et al., 1983). Hence, the concentration curves for $m^{7} G M P$ inhibition suggested that the mRNA from repressed cells, compared with that from the derepressed cells, may interact with lower affinity with initiation factors involved in cap recognition. In fact, when a preparation of initiation factors from rabbit reticulocytes was added to the reaction mixture, the translation of the mRNA from repressed cells was little affected by the presence of low $\mathrm{m}^{7} \mathrm{GMP}$ concentrations (up to $0.2 \mathrm{mM}$ ) and a concentration of $0.63 \mathrm{mM}$ was necessary to obtain $50 \%$ inhibition (Fig. $5 a$ ). In contrast, the presence of additional initiation factors did not significantly change the $\mathrm{m}^{7} \mathrm{GMP}$ inhibition curve of the protein synthesis directed by the mRNA from derepressed cells (the concentration causing $50 \%$ inhibition was slightly raised from 0.9 to $1.05 \mathrm{~mm}-\mathrm{m}^{7} \mathrm{GMP}$ ). Therefore, in the presence of $\mathrm{m}^{7} \mathrm{GMP}$, some initiation factors became limiting for the translation of the mRNAs from repressed cells.

The translation of mRNAs from both repressed and derepressed yeast cells were inhibited by aurintricarboxylic acid in a similar manner (Fig. $5 b$ ). This corroborated the above interpretation of the $m^{7}$ GMP inhibition studies, since the aurintricarboxylic acid interferes with Met-tRNA binding to $40 \mathrm{~S}$ ribosomal subunits and thus inhibits initiation in a step taking place before mRNA binding (Fresno \& Vazquez, 1979).

\section{DISCUSSION}

In order to increase the effect of catabolite derepression, yeast cells growing exponentially in high-glucose medium were transferred to a low-glucose medium since it has been reported that for some glucose-repressible enzymes, the amount or activity of the corresponding mRNAs was higher during natural depletion of glucose than during growth on ethanol-containing medium (Denis et al., 1983; Hoosein et al., 1984). Our results showed that the transfer of yeast cells from glucose-repressed to -derepressed conditions induced a change in the pool of yeast mRNAs translatable in a protein-synthesizing system from reticulocytes. Competition experiments with reticulocyte mRNAs showed that the mRNA population obtained from derepressed yeast cells possessed a higher translational efficiency than mRNA from repressed cells. Some mRNAs, which could account for the high translational efficiency of the derepressed mRNA preparation, were not detected in cells growing in high-glucose medium. However, the number of polypeptide bands specific to repressed or derepressed cells detected here must be considered an absolute minimum since our analysis detected only mRNAs that accumulated in substantial quantities.

The mRNA competition experiments discounted the possibility that the differences in translational capacity observed between $m R N A s$ from repressed and derepressed yeast were due to the presence of translational inhibitors in the mRNA preparation from repressed cells. On the other hand, although $\mathrm{m}^{7}$ GMP inhibition studies should be generally interpreted with caution, the translation of mRNAs from both repressed and derepressed cells appeared to be dependent on the cap structure since in the presence of high $\mathrm{m}^{7} \mathrm{GMP}$ concentrations neither messenger population was able to initiate protein synthesis. Nevertheless, the high susceptibility to this inhibitor of the translation of the mRNAs from repressed, as compared to derepressed cells, suggests that the initiation factors (or complex of factors) (Parets Soler et al., 1984; Ray et al., 1983; Sonenberg et al., 1981), recognizing the 5'-terminal structure of capped messengers, interact with lower affinity with the repressed than with some specific derepressed mRNAs. Indeed, in the presence of low $\mathrm{m}^{7} \mathrm{GMP}$ concentrations, the initiation factors became limiting for the translation of the mRNAs from repressed cells since the addition of reticulocyte initiation factors restored their translation. 
In yeast cells, it has been reported that the synthesis of proteins subject to carbon catabolite repression is due to novel synthesis of the corresponding mRNAs (Carlson \& Botstein, 1982; Denis et al., 1983; Federoff et al., 1983; Lustig et al., 1982; Perlman \& Halvorson, 1981; Szekely \& Montgomery, 1984), and not to activation of silent mRNAs stored as repressed mRNAs. Hence, the induction of enzyme activities during derepression is accompanied by an increase in the amount of translatable mRNAs corresponding to these enzymes. However, at least in the case of citrate synthase, a control attributable to RNA processing has not been discarded (Hoosein \& Lewin, 1984). Our results are consistent with the idea of a novel transcription of some specific mRNAs with high translational efficiency during derepression. Nevertheless, we cannot discount the possibility that covalent modifications of preexisting mRNAs play a role. For example, cap methylation could be involved in translational regulation of messengers present in repressed cells. Against this possibility one can argue that $S$. cerevisiae has been shown to contain only cap $O$ structures (Sripati et al., 1976), and no 2'-O-ribose methylase activity has been detected (Locht et al., 1983). However, since these determinations have been carried out with glucose-repressed cells, it remains to be established whether additional methylations of specific mRNAs became feasible during catabolite derepression.

In contrast to higher eukaryotic cells, $S$. cerevisiae is able to adapt rapidly to changes in environmental conditions. Thus, in response to certain adverse environments, such as glucose deprivation, it is conceivable that the yeast cell needs to rapidly synthesize large amounts of specific proteins with a limited number of mRNA templates. Our results indicate that this could be accomplished if the mRNAs induced by glucose deprivation are able to initiate protein synthesis efficiently and outcompete the translation of the mRNAs of minor physiological role in the new environmental state. However, further studies on yeast mRNA translation in repressed and derepressed $S$. cerevisiae cell-free systems should be undertaken to confirm this hypothesis.

This work was partially supported by grants from the Comisión Asesora de Investigación Científica y Técnica (grant no. 3432-83) and US-Spain joint Committee for Scientific and Technological Cooperation (CCB 8402/068).

\section{REFERENCES}

ADAMs, B. G. (1972). Induction of galactokinase in Saccharomyces cerevisiae: kinetics of induction and glucose effects. Journal of Bacteriology 111, 308-315.

BaldaCCI, G. \& ZenNaRo, E. (1982). Mitochondrial transcripts in glucose-repressed cells of Saccharomyces cerevisiae. European Journal of Biochemistry 127, 411-416.

Carlson, M. \& Botstein, D. (1982). Two differentially regulated mRNAs with different $5^{\prime}$ ends encode secreted and intracellular forms of yeast invertase. Cell 28, 145-154.

Chirgwin, J. M., Przybyla, A. E., MacDonald, R. J. \& RUTrER, W. J. (1979). Isolation of biologically active ribonucleic acid from sources enriched in ribonuclease. Biochemistry 18, 5294-5299.

Denis, C. L., Ferguson, J. \& Young, E. T. (1983). mRNA levels for the fermentative alcohol dehydrogenase of Saccharomyces cerevisiae decrease upon growth on a nonfermentable carbon source. Journal of Biological Chemistry 258, 1165-1171.

Elorza, M. V., Lostau, C. M., Villanueva, J. R. \& SENTANDREU, R. (1977). Invertase messenger ribonucleic acid in Saccharomyces cerevisiae kinetics of formation and decay. Biochimica et biophysica acta 475, 638-651.

Federoff, H. J., Eccleshall, T. R. \& Marmur, J. (1983). Carbon catabolite repression of maltase synthesis in Saccharomyces carlsbergensis. Journal of Bacteriology 156, 301-307.
Fresno, M. \& VAzQuez, D. (1979). Initiation of protein synthesis in eukaryotic systems with native 40S ribosomal subunits: effects of translation inhibitors. Methods in Enzymology 60, 566-577.

Gascon, S., Neuman, P. \& Lampen, J. O. (1968). Comparative study of the properties of the purified internal and external invertases of yeast. Journal of Biological Chemistry 243, 1573-1577.

HaARasilta, S. \& OURA, E. (1975). On the activity and regulation of anaplerotic and gluconeogenetic enzymes during the growth process of bakers' yeast. The biphasic growth. European Journal of Biochemistry 52, 1-7.

Hoosein, M. A. \& Lewin, A. S. (1984). Derepression of citrate synthase in Saccharomyces cerevisiae may occur at the level of transcription. Molecular and Cellular Biology 4, 247-253.

Ibrahim, N. G., Stuchell, R. N. \& Beattie, D. S. (1973). Formation of the yeast mitochondrial membrane. 2. Effect of glucose repression on mitochondrial protein synthesis. European Journal of Biochemistry 36, 519-527.

Kelly, R. \& Phillips, S. L. (1983). Comparison of the levels of the $21 \mathrm{~S}$ mitochondrial rRNA in derepressed and glucose-repressed Saccharomyces cerevisiae. Molecular and Cellular Biology 3, 1949-1957.

KIM, I. \& BEATTIE, D. S. (1973). Formation of the yeast mitochondrial membrane. 1. Effects of inhibition of protein synthesis on the kinetics of enzyme 
appearance during glucose repression. European Journal of Biochemistry 36, 509-518.

KRystosek, A., CAWTHON, M. L. \& Kabat, D. (1975). Improved methods for purification and assay of eukaryotic messenger ribonucleic acids and ribosomes. Quantitative analysis of their interaction in a fractionated reticulocyte cell-free system. Journal of Biological Chemistry 250, 6077-6084.

LAEMMLI, U. K. (1970). Cleavage of structural proteins during the assembly of the head of bacteriophage T4. Nature, London 227, 680-685.

Locht, C., Beaudart, J. L. \& Delcour, J. (1983). Partial purification and characterization of mRNA (guanine-7)-methyltransferase from the yeast $\mathrm{Sac}$ charomyces cerevisiae. European Journal of Biochemistry 134, 117-121.

LoDisH, H. F. (1974). Model for the regulation of mRNA translation applied to haemoglobin synthesis. Nature, London 251, 385-388.

Lustig, A., Levens, D. \& Rabinowitz, M. (1982). The biosynthesis and regulation of yeast mitochondria RNA polymerase. Journal of Biological Chemistry 257, 5800-5808.

Parets Soler, A., Reibel, L. \& Schapira, G. (1981). Differential stimulation of $\alpha$ - and $\beta$-globin mRNA translation by $M_{\mathrm{r}} 50000$ and 28000 polypeptidecontaining fractions isolated from reticulocytes polysomes. FEBS Letters 136, 259-264.

Parets Soler, A., Reibel, L. \& Schapira, G. (1984) The rate of initiation of $\alpha$ - and $\beta$-globin mRNA translation is modulated by $50 \mathrm{kDa}, 28 \mathrm{kDa}$ and $24 \mathrm{kDa}$ polypeptide-containing fractions. Biochemical and Biophysical Research Communications 120, 804-811.

Pel.haM, H. R. B. \& JaCKSON, R. J. (1976). An efficient mRNA-dependent translation system from reticulocyte lysates. European Journal of Biochemistry 67 , 247-256.

Perlman, P. S. \& Halvorson, H. O. (1981). Distinct repressible mRNAs for cytoplasmic and secreted yeast invertase are encoded by a single gene. Cell $\mathbf{2 5}$ 525-536.
Perlman, P. S. \& MaHLeR, H. R. (1974). Derepression of mitochondria and their enzymes in yeast: regulatory aspects. Archives of Biochemistry and Biophysics 162, 248-271.

Polakis, E. S. \& Bartley, W. (1965). Changes in enzyme activities of Saccharomyces cerevisiae during aerobic growth on different carbon sources. Biochemical Journal 97, 248-297.

Ray, B. K., Brendler, T. G., Adya, S., DanielsMCQueen, S., Miller, J. K., Hershey, J. W. B., Grifo, J. A., MERRICK, W. C. \& THACH, R. E. (1983). Role of mRNA competition in regulating translation: further characterization of mRNA discriminatory initiation factors. Proceedings of the National Academy of Sciences of the United States of America 80, 663-667.

Rovera, G., Magarian, C. \& Borun, T. W. (1978). Resolution of hemoglobin subunits by electrophoresis in acid urea polyacrylamide gels containing Triton X-100. Analytical Biochemistry 85, 506-518.

Sonenberg, N., Guertin, D., Cleveland, D. \& Trachsel, H. (1981). Probing the function of the eukaryotic 5 cap structure by using a monoclonal antibody directed against cap-binding proteins. Cell 27, 563-572.

Sripati, L. E., Groner, Y. \& Warner, J. R. (1976) Methylated, blocked $5^{\prime}$ termini of yeast mRNA Journal of Biological Chemistry 251, 2898-2904.

Staehelin, T., ERn, B. \& Schreier, M. H. (1979). Purification and characterization of seven initiation factors for mammalian protein synthesis. Methods in Enzymology 60, 136-165.

ST JohN, T. P. \& Davis, R. W. (1981). The organization and transcription of the galactose gene cluster of Saccharomyces. Journal of Molecular Biology 152, 285-315.

Szekely, E. \& Montgomery, D. L. (1984). Glucose represses transcription of Saccharomyces cerevisiae nuclear genes that encode mitochondrial components. Molecular and Cellular Biology 4, 939-946. 